\title{
7 \\ The Evolution of Australian Official War Histories
}

\author{
David Horner
}

Robert O'Neill was the third of Australia's six official war historians, and directly or indirectly had a major influence on at least four of the official history series - his own and the three succeeding official histories. When $\mathrm{O}^{\prime}$ Neill was appointed official historian for the Korean War in 1969, Australia had already had two official historians Charles Bean and Gavin Long. O'Neill would need to draw on the experiences of his two successors, but also make his own decisions about what was needed for this new history. The two previous official histories provided much guidance.

The first official historian, Charles Bean, was general editor and principal author of the Official History of Australia in the War of 19141918, published between 1921 and 1942 in 15 volumes. This official history set the benchmark for later Australian official histories. Bean believed that his history had at least six objectives. First, it was largely a memorial to the men who had served and died. Second, he needed to record in detail what the Australians had done, in the belief that no other nation would do so. Third, the narrative needed to provide sufficient evidence to sustain the arguments presented in it. Fourth, as the war had been 'a plain trial of national character, it was necessary to show how the Australian citizen reacted to it'. This meant that Bean needed to bring to life the experiences of the men in the front line. 
Fifth, Bean hoped that his history might 'furnish a fund of information from which military and other students, if they desired, could draw'. Finally, if possible, he wanted to tell the story from the Turkish and German sides as well as Australia's. ${ }^{1}$

By comparison with previous European official histories, Bean's history was unique in that it gave equal weight to the experiences of the soldiers and the decisions of commanders, and did not consciously try to draw lessons for future officers and commanders. The First World War series consisted of seven volumes on army operations, one each on the navy, the flying corps, the campaign in New Guinea, and the home front, as well as a photographic record. Bean wrote six of the army volumes. Only one, the home front volume, was written by a university-based historian. Three medical volumes were initiated some years later and were brought under Bean's general editorship. There was little coverage of higher strategic issues, partly because the Australian Government was only marginally involved in them.

Bean's history established an expectation that there would be a similar series for the Second World War, and he was instrumental in initiating it. On his recommendation, in March 1943 the government appointed Gavin Long as official historian for the Second World War. Following Bean's lead, Long travelled through the Southwest Pacific conducting interviews with officers and soldiers, and recording them in 134 diaries and notebooks. The Second World War official history, Australia in the War of 1939-1945, published between 1952 and 1977, consisted of 22 volumes, including seven on the army, two on the navy, four on the air force, two on the government and the people, two on the economy, and one on science and industry. Long wrote three of the army volumes, and 13 other authors wrote the remaining 19 volumes. Only the economic and science and industry volumes were written by university-based historians. As Bill Sweeting (one of Long's research assistants) wrote: 'It was the largest historical project ever undertaken in Australia.' ${ }^{2}$

1 Bean, C. E. W. (1961) Anzac to Amiens, Canberra: Australian War Memorial, p. viii.

2 Sweeting, A. J. (2000) 'Long, Gavin Merrick (1901-1968)', Australian Dictionary of Biography, Vol. 157, Melbourne: Melbourne University Press. Available at: adb.anu.edu.au/ biography/long-gavin-merrick-10856/text19269. 
While Bean continues to receive recognition for his achievement, with the publication of four biographies and discussion in numerous books and articles, Long has received less recognition. But his work was equally as impressive. His own accounts brought the experience of individuals alive in the same manner as Bean, and he raised contentious issues that set the agenda for further research, such as command problems and whether the final campaigns were necessary. ${ }^{3}$

The treatment of the home front was groundbreaking research. Australia's involvement in the Second World War was more complex than in the First World War. Australia's role as part of a larger allied coalition needed to be described, and the political story was fundamental to the history. To a greater extent than Bean, Long faced the problem of dealing with intelligence sources, but it is possible that he was never informed about the breaking of the German and Japanese codes, which only started to be revealed in the 1970s. Further, while the Secretary of the Department of Defence, Sir Frederick Shedden, who had been secretary of the War Cabinet, provided Long with whatever documents he requested, he did not offer Long documents that Long did not know existed. Although Long had originally planned a separate volume on general defence policy, this did not eventuate. No doubt Shedden hoped that his own history of Australian defence policy, written after he retired, would fill this gap, but it did not prove suitable for publication. ${ }^{4}$

Following the precedent of Bean's history, the government undertook to provide Long with 'reasonable access to official records', and decided that 'the exercise of censorship by the Government is to be limited to the preservation of disclosure of technical secrets of the three services which it is necessary to preserve in the post-war period'. Long acknowledged that while he and his colleagues had been given access to official papers, they were 'conscious of the special responsibilities which rest upon writers of a national history'. ${ }^{5}$ These were to become the guiding principles for the later official histories.

3 See Long, Gavin (1963) The Final Campaigns, Canberra: Australian War Memorial.

4 Horner, David (2000) Defence Supremo: Sir Frederick Shedden and the Making of Australian Defence Policy, Sydney: Allen \& Unwin, chapter 15.

5 Long, Gavin (1952) To Benghazi, Canberra: Australian War Memorial, pp. x, xi. 
In the decades after the Second World War, the idea of writing official histories of Australia's involvement in the Korean War, the Malayan Emergency, Confrontation, and the Vietnam War languished. The First and Second World Wars had been great national endeavours involving hundreds of thousands of citizens. By contrast, the Korean War and the Malayan Emergency were fought by regular servicemen, and the nation at large was not closely involved. In the Vietnam War, the regulars were supplemented by national servicemen. The contentious nature of the war meant that there was no immediate call for an official history.

Robert O'Neill played a key role in reviving the idea of writing official histories of these more recent conflicts. As a teenager, he had become interested in the official histories of the two world wars. He graduated from the Royal Military College (RMC), Duntroon, in 1958 and from 1961, as a Rhodes Scholar, he was a graduate student at the University of Oxford. His supervisor, Norman Gibbs, the Chichele Professor of the History of War, was then working on a volume of the British official history of the Second World War. O'Neill met Michael Howard, who would also write a volume in the British official history. (Both Howard and $\mathrm{O}^{\prime}$ Neill would later become Chichele Professor of the History of War.) O'Neill also met Brian Melland, of the Historical Section of the British Cabinet Office, and Noble Frankland, the author of a volume of the British official history and the Director of the Imperial War Museum. O'Neill had close contact with Sir Basil Liddell Hart, a professed critic of official histories, based on his own experience of the First World War, and the published volumes on that war.

O'Neill returned to Australia in 1966 and served with the 5th Battalion, Royal Australian Regiment (5RAR) in South Vietnam in 1966-1967. In 1966, his PhD thesis at Oxford was published as The German Army and the Nazi Party, 1933-1939, ${ }^{6}$ and the success of this book encouraged him to write a book about his battalion's experiences in Vietnam. The result was Vietnam Task, published in 1968. ${ }^{7}$

6 O'Neill, Robert (1966) The German Army and the Nazi Party, 1933-1939, London: Cassell. 7 O'Neill, Robert J. (1968) Vietnam Task: The 5th Battalion, Royal Australian Regiment, 1966-67, Sydney: Cassell. 
After Vietnam, O'Neill went to the RMC Duntroon as a lecturer, where the History Department of the Faculty of Military Studies was headed by Professor L. C. F. (Len) Turner, who had been joint author of three volumes of the South African official history of the Second World War. (As a cadet at Duntroon at this time, I was taught by Turner and $\mathrm{O}^{\prime}$ Neill.) Turner and O'Neill agreed that work needed to start on official histories of Australia's more recent conflicts, and chronologically, the first one was the Korean War. In the meantime, the Army's Director of Infantry, Colonel David Thomson, had persuaded O'Neill to begin a history of the Royal Australian Regiment.

While in Britain in the early 1960s, O'Neill had met Air ViceMarshal Geoff Hartnell, who was at Australia House and on the Board of Trustees of the Imperial War Museum. By 1969, Hartnell was a member of the Council of the Australian War Memorial and he took up the case for the official history of the Korean War. The Memorial Council and Director Bill Lancaster successfully sought funds for a Korean War history, and $\mathrm{O}^{\prime} \mathrm{Neill}$ and Turner were asked to accept the task. Turner withdrew, but $\mathrm{O}^{\prime}$ Neill agreed to continue the task alone and was officially appointed in December 1969. He stopped work on the history of the Royal Australian Regiment. Eighteen years later, the then director of infantry asked me to write the history of the Royal Australian Regiment. I enlisted other authors to assist and the book, Duty First, was duly published in $1990 .{ }^{8}$ Early parts of the book were based on an unpublished manuscript, 'History of the Royal Australian Regiment, 1945-1950', written by O'Neill in 1969.

O'Neill had already accepted an appointment in the Department of International Relations at The Australian National University. Once he arrived in early 1970, he found that Dr Tom Millar was stepping down as Head of the Strategic and Defence Studies Centre (SDSC) to become Director of the Australian Institute of International Affairs. The Head of International Relations, Professor Hedley Bull, asked O'Neill to take over as Head of SDSC. O'Neill then started work on two major tasks, headship of SDSC, and the official history of the Korean War.

8 Horner, David (ed.) (1990) Duty First: the Royal Australian Regiment in War and Peace, North Sydney: Allen \& Unwin. 
In anticipation of the appointment of an official historian for the Vietnam War, O'Neill also began to agitate for work to begin on collecting historical material. This yielded results, and Lieutenant Colonel Robin Morison was sent to Vietnam in charge of record making and gathering. $\mathrm{O}^{\prime} \mathrm{Neill}$ visited him there in 1971 to give a little guidance on what would be most valuable for a war historian. $\mathrm{O}^{\prime}$ Neill advised the army to set up an oral history project, and over the next two years Morison interviewed more than a score of senior officers who had served in Vietnam. Morison was joined in this endeavour by Major Ian McNeill, who would later write one and part of another of the combat volumes of the Vietnam War official history.

Because the Korean War history was being undertaken on a shoestring budget, $\mathrm{O}^{\prime}$ Neill had to proceed alone, although after a few years he was joined by a research officer, Darryl McIntyre. O'Neill worked on the official history at the Australian War Memorial or government offices (where he researched external affairs and defence files) during the morning and ran SDSC in the afternoon. Later, on study leave in Britain, he worked in the Imperial War Museum and the British Ministry of Defence, where he researched British documents, including the war diaries of British formations of which the Australian battalions were part (and which were not available in Australia).

Bean and Long had first-hand experience of many operations. O'Neill had not served in the Korean War, but had operational service in Vietnam. Unlike Bean and Long, however, $\mathrm{O}^{\prime} \mathrm{Neill}$ had a PhD in history and had written books on military history before he was appointed. Coming to the task some 20 years after the Korean War and having no personal experience of the war, $\mathrm{O}^{\prime} \mathrm{Neill}$ drew on his training as an academic historian. Clearly, he needed to research the files of the various Australian Government departments and also those of the United Kingdom, but to supplement the information in the files he sought to interview the participants. He was assisted by two former secretaries to the Department of External Affairs, Sir James Plimsoll and Sir Alan Watt, and especially by the former Minister for External Affairs, Sir Percy Spender, who played the key role in committing Australian troops to the Korean War and in bringing the ANZUS Treaty to fruition. 
As he researched these files, O'Neill realised that the diplomatic and strategic aspects were the most important part of the story. He observed that 'there was very little interaction between Australian strategic policy and the combat operations of Australian forces in the Korean war', and hence any 'attempt to produce an integrated history, treating Australian policy development and Australian military operations as part of a continuous pattern of related activity, would have been highly artificial'. ${ }^{9}$ As a consequence, the first volume of Australia in the Korean War 1950-1953, published in 1981, dealt with strategy and diplomacy, and the second volume, published in 1985, covered combat operations of the three services.

Volume II was divided into four parts - the land, air wars, sea wars, and a final part on prisoners, medical aspects, and post-armistice operations. It maintained the tradition of telling the story from the soldiers' perspective. As a former army officer who had seen active service of his own, $\mathrm{O}^{\prime}$ Neill understood army operations, but he also needed to comprehend naval and air operations for those sections of his history. Bean had left the writing of the naval and flying corps volumes to other authors, just as Long had left the naval and air force volumes to those with specialist knowledge. While commanders' diaries and reports of proceedings were vital sources, $\mathrm{O}^{\prime}$ Neill conducted interviews or sought advice from more than 70 participants.

The official history was an outstanding achievement, which not only upheld the very high standards of its predecessors, but set new standards. For example, the Korean War official history had a detailed bibliography and footnotes to documents, which had not generally been the case in the earlier official histories. It was important to put the experience of the servicemen on record, and in this respect the history has become the key source for information on the Australian operations - just as the Bean and Long histories have been the starting point for future research. But beyond this, the history was a major advance in the historiography of Australian diplomacy during a time when Australia was developing its own foreign policy. Volume I is still the most authoritative account of the establishment of the ANZUS alliance.

9 O‘Neill, Robert (1981) Australia in the Korean War 1950-1953, Vol. I: Strategy and Diplomacy, Canberra: The Australian War Memorial and the Australian Government Publishing Service, p. xv. 
Most importantly, the Korean War history revived the concept of official histories in a modern setting. It provided a bridge between the official histories of the world wars and those of Southeast Asian conflicts and beyond. Like the world wars, the Korean War history dealt with only one war. But, like subsequent series, the Korean War history showed that the political and diplomatic history was just as important as recounting what happened on the battlefield.

I received my first glimpse of the challenges of writing an official history when O'Neill supervised my master's thesis from 1974-1975, and my PhD thesis from 1978-1980 (the latter undertaken at ANU). After Duntroon, I had served as an infantry officer in Vietnam, and during those periods of postgraduate study I was still serving in the Australian Army. At that time, $\mathrm{O}^{\prime}$ Neill was working on his official history. He discussed some of the challenges and at one stage asked me to read the army sections of Volume II. I am not sure that I had any useful comment to make at that point of my development as a historian. My interest in official histories was sparked, however, when I found that Gavin Long's plan to write a volume on strategic and defence policy had not been fulfilled, and that he had not been given full access to the papers of Sir Frederick Shedden. I determined that my $\mathrm{PhD}$ thesis on Australian strategic policy-making in the Second World War, for which I had access to the Shedden papers, would try to fill this gap in the Australian official history. It was published in 1982 as High Command: Australia and Allied Strategy 1939-1945. ${ }^{10}$ My time working with $\mathrm{O}^{\prime} \mathrm{Neill}$ helped shape my approach when I later became an official historian.

In 1982, Dr Peter Edwards was appointed official historian for the Vietnam War, 10 years after the last combat troops withdrew. O'Neill was not directly involved in persuading the government to approve the history, but he was a member of the selection committee for the official historian and provided guidance. The Official History of Australia's Involvement in Southeast Asia Conflicts 1948-1972, marked a further step in the development of Australian official histories. Edwards, like O'Neill, was a Rhodes Scholar. He had a PhD in history and had written or edited books on Australian diplomatic history; but he had no military service and had not visited Vietnam during the Vietnam

10 Horner, David (1982) High Command: Australia and Allied Strategy 1939-1945, Canberra: Australian War Memorial. 
War. This was not, however, an impediment to producing a thorough history, as he concentrated on strategy, diplomacy, and politics. Of his other six principal authors, only Ian McNeill had served in the Vietnam War, but all had university training as historians.

Edwards confirmed the model set by $\mathrm{O}^{\prime} \mathrm{Neill}$ in emphasising the importance of strategy and diplomacy. His history covered three conflicts - the Malayan Emergency (1948-1960), Confrontation (1963-1966), and the Vietnam War (1972-1975) - and his first volume on politics and diplomacy dealt with the background to the deployments in these conflicts. As with the earlier official histories, the Vietnam series dealt separately with the three services in Vietnam. The series ran to nine volumes, two on politics and diplomacy, one on the Emergency and Confrontation, three on land operations in Vietnam, one on air operations in Vietnam, one on naval operations in the Southeast Asia region, and one on medical aspects.

Both the O'Neill and Edwards histories suffered from the parsimony of governments. Edwards received no direct funding for several of his authors, so he persuaded two authors to write volumes as part of their university research projects, and the author of the RAAF volume was funded by the RAAF. The result was that although the first volume, Crises and Commitments, was published in 1992, 10 years after the beginning of the project, the last volume, Fighting to the Finish, did not appear until 2012, more than 40 years after the last combat troops withdrew from Vietnam. By this time, the youngest men who served in Vietnam were in their 60s. There was one advantage in this. The author, Ashley Ekins, was able to make use of recently available Viet Cong histories, deal with the arguments in other books, and tie up loose ends. But a long-delayed history should not be a model for the future. The series was deeply researched, measured in judgments, respectful of the achievement of the Australian service people, and superbly presented. 
Successive official historians have sought to persuade governments to initiate new histories. Edwards tried to persuade the government to initiate an official history of Australian peacekeeping operations, but in 1992 the Minister for Veterans' Affairs declined to support a history while the Vietnam official history was uncompleted. ${ }^{11}$

As the Vietnam official histories started to appear, some historians questioned whether official histories had outlived their usefulness. For example, in 1994, the academic historian John Murphy argued that Edwards failed to provide a full portrait of Australian society and politics, and that his series consisted of books that were divided into specialist sub-disciplines of diplomatic and military history. Murphy concluded:

Bean and Long were both journalists, writing for a wider audience; McNeill and Edwards are writing within more specialised discourses. In these senses the tradition of official history seems problematic and near to exhaustion. Where before it meant an attempt to explain the social experience of war, it has been diverted into the scholarly study of war as seen from the commanding heights of the cabinet, bureaucracy and armed forces. ${ }^{12}$

Glen St J. Barclay of the University of Queensland made a similar criticism. He acknowledged that the official historians of both world wars 'set a magnificent standard', but asserted that 'it could not be sustained'. It was possible, he said, 'to write exclusively and in vast detail about Australia's involvement in the two World Wars because Australians had played a significant part in their own right in many campaigns in both conflicts', but, he added, 'it would not be possible to write exclusively about Australian involvement in conflicts in which Australian units operated as marginal elements in a vast largely Allied operation' without producing an account for which the audience 'would certainly be prone to miss the point'. Thus, while O'Neill's

11 In 1991, the Senate Standing Committee on Foreign Affairs, Defence and Trade recommended that the Vietnam official historian be commissioned to write the history of Australian peacekeeping.

12 Murphy, John (1994) 'The New Official History', Australian Historical Studies 26(102), pp. 123-4. 
volume Strategy and Diplomacy had been an 'unqualified success', his second volume, Combat Operations, although well done, was 'precisely a regimental history' which omitted the larger picture. ${ }^{13}$

The argument that Bean and Long were trying primarily to explain the social experience of war is hard to sustain, given their detailed treatment of operations. It seems that Murphy and Barclay were arguing that $\mathrm{O}^{\prime} \mathrm{Neill}$ and Edwards failed because they did not exactly follow, or more generally because it was no longer possible to follow, the model of previous histories. Did that mean that the concept of official histories had outlived their usefulness? Or could it be that there were new models with their own utility?

This was one of the questions I needed to deal with in 2002 when the Australian War Memorial engaged me to conduct a study into the feasibility of an official history of Australian peacekeeping. By that time I had retired from the Australian Army and was working in SDSC at ANU. As part of my feasibility study, I sought advice from both O'Neill and Edwards.

The arguments in favour of a new official history seemed persuasive. Despite the relatively few casualties - in all less than a dozen deaths - the operations were often extremely arduous and dangerous, and the absence of heavy casualties could be attributed about equally to excellent planning and training, and plain luck. Further, while Australia suffered few casualties, the conflicts involved very large numbers of deaths, including some of the great tragedies of the twentieth century. For example, hundreds of thousands were killed in Rwanda. The psychological impact on the Australians was considerable and many peacekeepers had been diagnosed with posttraumatic stress disorder.

The nature of Australian military operations had changed. We are unlikely to again see operations on a scale of the world wars. The operations in recent years, however, had played a large part in defining Australia's place in the world, and were similar to those that were likely to occur in the future. More broadly, Australia had shown that it was a good international citizen, and decisions had not been

13 Barclay, Glen St John (1995) 'Australian Historians and the Study of War, 1975-88', Australian Journal of Politics and History 41, pp. 240-53. 
taken lightly. For example, there was probably more government consideration given to Australia's commitments to Somalia and Cambodia than was given to Australia entering the First World War. Many operations required complicated defence planning. An official history would need to discuss the reasons for the conflicts and the background to Australia's involvement. On a more personal level, the men and women of the Australian Defence Force (ADF) had become widely admired for their professionalism, reliability, and compassion. They had been truly representing Australia abroad. The history would therefore need to describe the activities of the Australians in the operations, even when relatively small numbers were deployed.

We now live in a society in which people demand more recognition than in the past. Service people expect medals and compensation for injuries. They feel that they too deserve to be treated as Anzacs. The feeling among veterans that service in peacekeeping operations was special and had not been recognised sufficiently was illustrated by the formation of the Australian Peacekeeping and Peacemakers Association in October 1997.

An official history of peacekeeping would face some intellectual challenges. By contrast with the first four series, the fifth series would need to deal with at least 50 missions in about 27 conflicts (as was the case when I did the feasibility study in 2002), many taking place at about the same time in a wide range of geographic areas. The fifth series would cover a period of more than 60 years - from 1947 to 2006 - and the authors would need to comprehend the domestic and international political environments across this entire period.

One obvious difference was that the first four series dealt with wars in which Australia was a participant. Within the bounds of proper scholarship, these could be partisan histories. To my knowledge, noone suggested that Gavin Long and his authors should go easy on describing instances of Japanese barbarism because to do so might offend the Japanese. By contrast, the fifth series needed to deal, to a large extent, with missions in which the Australians were not protagonists in the conflict, but stood between the protagonists. Often Australia tried to maintain good relations with both sides of a conflict. How was the history to deal with situations in which Australian peacekeepers might have reported on the poor behaviour of one of 
the sides? In a similar vein, all the Australian deployments had been part of a multinational force, often composed of strange bed-fellows. Should we report on the unsatisfactory conduct of our allies?

One key question to be addressed was whether Australia's contributions actually made a difference. This question was never explicitly examined in the previous official histories, although they provide sufficient evidence for readers to draw their own conclusions. What difference did the Australians make by their presence in, say, the United Nations Truce Supervision Organisation in the Middle East? What was the value of Australia's contribution in Western Sahara, where the deadlock continues to the present day, even though the Australians withdrew more than two decades ago? And if the value of Australia's contribution was qualitative, rather than quantitative, who is able to make the judgement? Do we rely on the Australian troops' estimation of their own worth?

The first four official histories series described conflicts within particular paradigms for the use of force. These paradigms have undergone significant changes. The strategic environment since the end of the Cold War has seen the emergence of forms of warfare whose characteristics include ethnic conflict within countries; the influence of international media; the Revolution in Military Affairs and the development of network-centric warfare; the use of the precision strike; the use of special forces rather than large-scale deployments; the campaign against international terrorism; the increasing importance of operations other than war; the increasing importance of joint and coalition operations; the increasing role of non-government organisations (NGOs); and the deployment of women on operations. These characteristics were not present in the conflicts described in the earlier official histories.

In addition, there were special characteristics of peacekeeping that needed explanation, including the problems caused by restrictive rules of engagement, with soldiers being required to observe atrocities but not being permitted to intervene; the command and management problems of operating under United Nations rather than national control; the problem of 'mission creep' - for example, a humanitarian operation that might turn into a peace enforcement operation; the political sensitivity of many operations, with the government wishing to retain good relations with the protagonists; the problems 
of operating as part of a coalition that might include countries with entirely different political and military cultures; situations in which almost every action has political ramifications; and the involvement of many agencies, including other UN agencies and NGOs. These considerations meant that the old models of the official histories were no longer appropriate. A new and innovative approach would be needed for a modern official history.

The Australian War Memorial accepted my feasibility study, and in March 2004 I was appointed official historian. But government parsimony reached an all time high. No government money was specifically allocated for the project. The Director of the Australian War Memorial, Major General Steve Gower, and I cobbled together funds from various sources - the Australian War Memorial (from its operating budget), the Department of Defence, ANU, and the Australian Research Council - to allow the project to begin. I was able to engage authors and research assistants, but for only a limited period. As with the Vietnam history, all the authors had university training as historians. Dr Bob Breen had been a Regular Army officer and had spent considerable time visiting Australian forces on various operational deployments. Two other authors had Army Reserve service. The final Official History of Australian Peacekeeping, Humanitarian and Post-Cold War Operations consisted of:

- Volume I: The Long Search for Peace: Observer Missions and Beyond: 1947-2006

- Volume II: Australia and the 'New World Order': From Peacekeeping to Peace Enforcement: 1988-1991

- Volume III: The Good International Citizen: Australian Peacekeeping in Asia, Africa and Europe, 1991-1993

- Volume IV: The Limits of Peacekeeping: Australian Missions in Africa and the Americas: 1992-2006

- Volume V: The Good Neighbour: Australian Peace Support Operations in the Pacific Islands, 1980-2006

- Volume VI: In Their Time of Need: Australia's Overseas Emergency Relief Operations, 1918-2006. 
At the time of writing (December 2015), Volumes II and III had been published, Volume V was with the publisher, Volume VI was being cleared by government departments, and it was hoped that final drafts of Volumes I and IV would be completed by 31 March 2016.

This structure revealed substantial differences from earlier series. The government's policy considerations for each mission were included as part of the story of each mission, although each volume also had several chapters discussing the government's general approach to peacekeeping. There was no separate treatment of the different services. Some missions were conducted by mainly army or naval units, but in general the ADF now deployed in joint service task groups. There was no medical volume or section. Medical units deployed to northern Iraq and Rwanda, but they were covered in the same manner as other missions - i.e. as part of the general peacekeeping story. There were, however, appendices on post-traumatic stress disorder and Gulf War syndrome. It might be noted that the Australian operations in East Timor which began in 1999 were not included in this series, no doubt because of government sensitivities about offending Indonesia. I tried to have East Timor included in the series but was unsuccessful.

By the time I was appointed official historian in 2004, I had become convinced that work needed to begin on another official history, covering Australian military operations in Afghanistan and Iraq. Following the terrorist attacks in New York and Washington DC on 11 September 2001, the ADF sent troops into Afghanistan in October 2001. The troops departed in 2002, but returned to Afghanistan in 2005 and served there until 2014 when the commitment formally ended (although some troops remained). In 2003, Australia joined with the United States and the United Kingdom in taking part in the invasion of Iraq. Most of the Australian force withdrew soon after the initial campaign, but forces returned to Iraq in 2005 and remained there until 2009. Due to the political sensitivity of many of the operations, the Australian public, and indeed the troops themselves, had no idea what operations had actually been conducted, or why.

After agitating for many years, in 2011 I persuaded the Australian War Memorial to commission a feasibility study into an official history of Iraq and Afghanistan. I undertook the study in 2012 and concluded that an official history could be justified on three broad grounds. First, the experience of past official histories re-affirmed the 
requirement for detailed, authoritative accounts of Australia's military operations - a need strengthened by the increasing importance of policy issues and the requirement to provide authority for compensation and pension benefits. There was a public expectation that Australia's official history tradition would continue. Second, the operations in Iraq and Afghanistan, involving perhaps 30,000 Australians over 10 years, had clearly been of sufficient magnitude and complexity to warrant an official history. Third, because of restrictions on Australian journalists, the history of these activities had not been covered adequately in existing works.

There were compelling reasons why an official history should begin as soon as practicable. The operations had been running for more than a decade, casualties had been mounting and the Australian public had a right to know how and why the operations had been conducted. The ADF personnel who served there deserved to have their stories told. The operations were complex and long-running, and as each year passed it would become increasingly difficult to locate the information necessary to write an authoritative history. Most records in government departments are now held digitally, and there are particular problems in accessing highly classified records on digital systems.

Several reasons were advanced as to why such a history should not be written at that time. Some people argued that sufficient time needed to pass before past events could be seen in proper historical context. Yet previous governments had approved research for the official histories of the First and Second World Wars to begin during those wars. If an official history of Iraq and Afghanistan were to be authorised in 2013, the events of 2001-2002 would likely be covered in the first volume of the history. This volume would be published at the earliest in 2020 - some 18 years after the events concluded.

Certain officials argued that the events surrounding the operations in Iraq and Afghanistan were too sensitive, and might still be sensitive in 20 years' time. Australian operations were conducted as part of an allied coalition and it would be too difficult, perhaps impossible, to reveal the negotiations with Australia's coalition partners. More so than in the past, recent operations have been driven by intelligence; the sources and nature of this intelligence should remain secret. If an official history were to be approved there might be problems in clearing it for publication. Indeed, the experience of the peacekeeping 
official history showed that government departments were likely to try to censor the history, notwithstanding the cabinet minute stating that there was to be no censorship. Although we now live in an era of greater government transparency, governments have become even more determined to keep their decision-making considerations secret.

The Council of the Memorial agreed that a history was feasible and should begin as soon as possible, but attempts to obtain government approval were delayed by two changes of government during 2013 Prime Minister Julia Gillard was replaced by Kevin Rudd in mid-2013 and in turn he was defeated in a general election by the Coalition, led by Tony Abbott. In April 2015 the Abbott Government approved and agreed to fund the official history of Iraq and Afghanistan, and added funding for a volume on East Timor. At the time of writing, the government had not announced the new official historian. The new official history will be a major undertaking - one which will bring about a further evolution in the nature of Australian official histories.

Robert $\mathrm{O}^{\prime}$ Neill had no direct influence over the official history of Iraq and Afghanistan. But there was considerable indirect influence. His agitation in 1969 had led to the Australian War Memorial Council taking the key role in presenting the case to the government, and that approach from the council has persisted through to the present time, leading to the Vietnam, peacekeeping and Iraq/Afghanistan official history series. As O'Neill's student, I was strongly influenced by his approach to official histories and historical scholarship in general. I was able to use that knowledge and experience not only as official historian of peacekeeping, but also in setting the ground work for the Iraq/Afghanistan series. Robert O'Neill has made an outstanding contribution to scholarship and public debate in the field of strategic studies (as discussed in other chapters). His major contribution in keeping Australian official histories alive, contributing to their evolution, and in fostering them should not be overlooked. 
This text is taken from War, Strategy and History: Essays in Honour of Professor Robert O'Neill, edited by Daniel Marston and Tamara Leahy, published 2016 by ANU Press, The Australian National University,

Canberra, Australia. 